Rossiter, R. J. (1940). J. biol. Chem. 135, 431.

Rydin, H. (1935). Biochem. J. 29, 860.

Schlenk, F. and Snell, E. E. (1945). J. biol. Chem. 157, 425.

Sealock, R. R., Livermore, A. H. and Evans, C. A. (1943). J. Amer. chem. Soc. 65,935 .

Silverman, M. and Werkman, C. H. (1939). Iowa St. Coll. J. Sci. 12, 107.

Silverman, M. and Werkman, C. H. (1941). J. biol. Chem. 138, 35 .

Sinclair, H. M. (1933). Biochem. J. 27, 1927.

Sober, H. A., Lipton, M. A. and Elvehjem, C. A. (1940). J. biol. Chem. 134, 605.

Still, J. (1941). Biochem. J. 35, 380.

Straub, F. B. (1939). Biochem. J. 33, 787.

Straub, F. B. (1940). Biochem. J. 34, 483.

Suzuki, U., Shimamura, T. and Odake, S. (1912). Biochem. Z. 43, 89.

Teague, P. C. and Williams, R. J. (1942). J. gen. Physiol. 25, 777.

Theorell, H. (1934). Biochem. $Z$. 275, 344.

Theorell, H. (1935). Biochem. Z. 278, 263.

Theorell, H. (1936, 1), Biochem. Z. 288, 317.

Theorell, H. (1936, 2). Nature, Lond., 138, 687.

Theorell, H. (1937). Biochem. Z. 290, 293.

Thompson, R. H. S. (1934). Biochem. J. 28, 909.

Trufanov, A. V. (1941). Biokhimia, 6, 301.

Warburg, O. and Christian, W. (1932). Biochem. Z. 254, 438.

Warburg, $O$, and Christian, W. (1933). Biochem. Z. 266, 377.

Warburg, O. and Christian, W. (1934). Biochem. Z. 274, 112.

Warburg, O. and Christian, W. (1935). Biochem. Z. 275, 464.

Warburg, O. and Christian, W. (1936). Biochem. Z. 287, 291.

Warburg, O. and Christian, W. (1938). Biochem. Z. 298, 150.

Warburg, O. and Christian, W. (1939). Biochem. Z. 303, 40.

Warburg, O., Christian, W and Griese, W. (1935). Biochem. Z. 282, 147.

Weil-Malherbe, H. (1939). Biochem. J. 33, 1997.

Williams, R. J., Mosher, W. A. and Rohrmann, E. (1936). Biochem. J. 30, 2036.

Woods, D. D. and Trim, A. R. (1942). Biochem. J. 36, 501.

\title{
Some Recently Characterized Members of the Vitamin $\mathrm{B}_{2}$ Complex
}

\section{Mr. F. A. Robinson (Glaxo Laboratories, Ltd., Greenford, Middlesex)}

The best known members of the vitamin $B_{2}$ complex aro riboflavin and nicotinic acid which, together with vitamin $B_{1}$, are responsible for certain clearly defined deficiency diseases. The distinction between these factors and the other members of the vitamin $B_{2}$ complex, which do not appear to be associated with specific deficiency diseases, is not as arbitrary as would appear at first sight, and one of the objects of this discussion is to emphasize the real difference that exists between the two groups.

In the course of work on the isolation of the pellagra preventive factor, concentrates were prepared from liver and yeast which not only cured pellagra in man and blacktongue in dogs, but also certain types of dermatitis in rats and chicks. It was subsequently shown that nicotinic acid or its amide was the pellagra preventive factor, and that this had no effect in rat or chick dermatitis. Elvehjem and Koehn (1935) showed that the ability of the crude concentrates to cure rat dermatitis was due to one factor, factor I or vitamin $B_{6}$, and the effect on chicks to another factor, factor II. Since the former was adsorbed on fuller's earth whilst the latter was not, the two factors were sometimes described as the eluate and filtrate factors, respectively. 
Pyridoxin

The eluate factor, vitamin $B_{6}$, or pyridoxin, was isolated in the pure crystalline state by György (1938), Keresztesy and Stevens (1938), Lepkovsky (1938), and Kuhn and Wendt (1938, 1, 2), and its constitution was determined by Kuhn and Wendt $(1938,3 ; 1939)$, and by Stiller. Keresztesy and Stevens (1939) and Harris, Stiller and Folkers (1939), It was synthesized by Harris and Folkers $(1939,1,2)$ by Kuhn, Westphal, Wendt and Westphal (1939) and by Ichiba and Michi (1939), each group working independently. Although pyridoxin has been known for over seven years, no satisfactory explanation of its biological function has been advanced until recently but, within the last few months, two suggestions have been made, one that it is a constituent of the co-enzyme of tyrosine decarboxylase (Gunsalus and Bellamy, 1944, 1, 2; Gunsalus, Bellamy and Umbreit, 1944), and the other that it is a co-enzyme essential for transamination reactions (Schlenk and Snell, 1945). In both instances, pyridoxin itself appears to be inactive, and a closely related compound, pyridoxal, is believed to be the active agent. Whereas the corresponding amino-compound, pyridoxamine, is ineffective as a tyrosine decarboxylase, the co-transaminase activity appears to depend on the interconversion of pyridoxal and pyridoxamine. The structures of pyridoxal and pyridoxamine were established by Harris, Heyl and Folkers (1944, 1, 2).

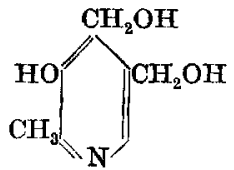

Pyridoxin<smiles>Cn1cc(O)c(C=O)n1</smiles>

Pyridoxal<smiles></smiles>

Pyridoxamine

These observations are in accord with the results of recent microbiological studies of pyridoxin and its derivatives. It was observed some time ago that, whilst pyridoxin will stimulate the growth of certain micro-organisms, another substance which accompanies it in foodstuffs, or is actually produced from it by the extraction procedure, has a still greater effect on the growth of these organisms. This substance, to which the name "pseudo-pyridoxin" was applied, has now been identified as a mixture of pyridoxal and pyridoxamine (Snell and Rannefeld, 1945). Both compounds were as effective as pyridoxin in stimulating the growth of rats, moulds and some yeasts, but were up to several thousand times more effective than pyridoxin in stimulating the growth of lactic acid bacteria. It is probable therefore that the active form of vitamin $B_{6}$ is not pyridoxin but pyridoxal.

\section{Pantothenic Acid}

The determination of the chemical structure for the filtrate factor proved to be more difficult than for the eluate factor. In the first place, it was not easy to purify and, even when relatively pure material was available, it had few characteristic reactions. It was not until its similarity to a substance known as pantothenic acid was established that progress was made.

Pantothenic acid is a constituent of bios, the hypothetical factor postulated by Wildiers (1901) as essential for the growth of certain yeasts. vor. 4, 1946] 
Its identity with the filtrate factor was established by the demonstration that pantothenic acid cured dermatitis in chicks (Jukes, 1939), whilst a filtrate factor concentrate stimulated the growth of micro-organisms (Subbarow and Hitching, 1939). Further work showed that pantothenic acid had the structure:<smiles>CC(O)C(C)(C)CO</smiles>

and its synthesis followed soon afterwards (Stiller, Harris, Finkelstein, Keresztesy and Folkers, 1940).

\section{Biotin}

Another constituent of bios is the substance biotin, which stimulates the growth of certain yeasts at the fantastic dilution of 1 in 400 thousand millions. By a laborious chemical fractionation of egg yolk, Kögl and Tönnis (1936) isolated a small quantity of crystalline biotin methyl ester. This was subsequently shown to be identical with a substance called vitamin $\mathrm{H}$, isolated by du Vigneaud, Hofmann and Melville (1941) from a liver concentrate, and capable of curing an eczema-like dermatitis in rats resulting from feeding with a high proportion of egg white. The substance in egg white responsible for this dermatitis was isolated in crystalline form by Pennington, Snell and Eakin (1942), and shown to be a heat labile protein with a large carbohydrate moiety; it is now called avidin. It inactivates biotin by combining with it to form an insoluble complex. In raw egg, all the biotin in the yolk is rendered completely unavailable by the avidin of the white but, on cooking, the avidin is destroyed and the biotin becomes fully available.

Biotin and pantothenic acid are essential growth factors for a wide range of micro-organisms, but their functions in the animal cconomy are by no means clear. Biotin has been said (du Vigneaud, Spangler, Burk, Kensler, Sugiura and Rhoads, 1942) to increase the incidence of cancer induced in mice by the administration of butter yellow, and it has been suggested that avidin may inhibit this particular form of cancer. The effect of biotin deficiency in human beings was tested by Sydenstricker, Singal, Briggs, de Vaughn and Isbell (1942), who gave a number of volunteers 30 per cent. of their calorie intake in the form of egg white. The symptoms observed were a scaliness of the skin, lassitude, muscle pains and hyperaesthesia, whilst the blood picture also was affected. All these symptoms were cured in three to five days by means of a biotin concentrate. The symptoms of biotin deficiency in monkeys were recently described by Waisman, McCall and Elvehjem (1945). No one has yet encountered an uncomplicated pantothenic acid or biotin defieiency in man not artificially induced, though this does not mean that these factors may not in due course have a specifie use in therapy.

The structure of biotin was established comparatively recently (du Vigneaud, Melville, Folkers, Wolf, Mozingo, Keresztesy and Harris, 1942; Melville, Moyer, Hofmann and du Vigneaud, 1942), and its 
synthesis has been described (Harris, Wolf, Mozingo, Anderson, Arth, Easton, Heyl, Wilson and Folkers, 1944). It has the structure:

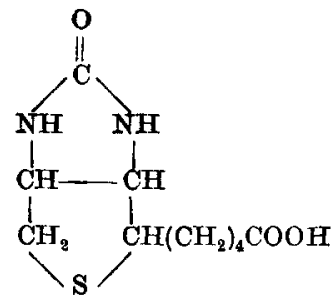

Soveral closely related compounds can replace biotin as a growth factor for yeasts, and pimelic acid, which was claimed by Mueller (1937) to be an essential growth factor for the diphtheria bacillus, appeans to be able to replace biotin for certain other micro-organisms, and may even be a precursor in its biological synthesis. Other substances related to biotin inhibit its growth promoting activity, and have antibacterial properties.

\section{Folic Acid, Vitamin $B_{0}$, Xanthopterin and Vitamin $M$}

A study of the growth requirements of bacteria has led to the recog. nition of yet another factor belonging to the vitamin $B_{2}$ complex. When certain organisms such as Lactobacillus casei $\epsilon$ (L. helveticus) and Streptococcus lactis $\mathrm{R}$ (S. faecalis) are transferred to a synthetic medium containing, in addition to amino-acids, all the members of the vitamin $B$ complex so far described, little or no growth occurs but, when concentrates prepared from liver, yeast or other sources are added, good growth occurs, and the name folic acid was given to the factor responsible, obtained by Mitchell, Snell and Williams (1941) from spinach leaves, hence its name. It was purified by adsorption on charcoal, elution, precipitation with lead and mercury salts, and chromatographic adsorption on fuller's earth. The preparation and properties of nearly pure folic acid were recently described in detail (Frieden, Mitchell and Williams, 1944; Mitchell, 1944; Mitchell, Snell and Williams, 1944; Mítchell and Williams, 1944).

It is probable that the story of folic acid will follow the pattern already set by that of biotin and pantothenic acid in that it now appears to be identical with a factor essential to the well being of animals. This is the so called vitamin $B_{c}$ first described by Richardson, Hogan and Karrasch (1942) and O'Dell and Hogan (1943). It is a growth factor for chicks which was isolated from liver by adsorption on fuller's earth and charcoal, and purified to yield orange yellow platelets which formed a crystalline methyl ester. The same substance, active for chicks, was obtained from liver and yeast (Stokstad, 1943; Hutchings, Stokstad, Bohonos and Slobodkin, 1944); the factor from yeast, however, proved to be less active than the liver factor as a growth stimulant for $L$. casei $\epsilon$ and was almost inactive for $S$. lactis $R$. Krueger and Peterson (1945), on the other hand, found vitamin $B_{c}$ to be equally active for both organisms whether prepared from yeast or from liver. Woolley and Sprince (1944) showed that vitamin $B_{c}$ was a growth factor for guineapigs.

voL. 4,1946$]$ 
Further support to the conclusion that vitamin $\mathrm{B}_{\mathrm{c}}$ and folic acid are identical is afforded by the work of Binkley, Bird, Bloom, Brown, Calkins, Campbell, Emmett and Pfiffner (1944) who found that concentrates of the factor prepared from yeast were essentially inert in stimulating the growth of $L$. casei $\epsilon$, but became highly active after enzymic digestion. From the digests a pure cystalline compound was isolated which stimulated the growth of $L$. casei $\epsilon$ and $S$. lactis $\mathrm{R}$ and cured the anaemia and improved the growth of chicks.

Campbell, Brown and Emmett (1944) were the first to report that crystalline vitamin $B_{c}$ prevented the development of anaemia and leucopenia in chicks fed on a synthetic diet, and Hill, Norris and Heuser (1944) found that folic acid also would prevent anaemia in chicks though only in presence of a second factor. Scott, Norris, Heuser, Bruce, Coover, Bellamy and Gunsalus (1944) reported that pyridoxin and the lactone of 2-methyl-3-hydroxy-4-hydroxymethyl-5-carboxypyridin, for which the name $\alpha$-pyracin is proposed, i.e., the lactone of the acid derived from pyridoxin promoted growth and prevented anaemia in chicks fed on a purified diet, and Scott, Norris, Heuser and Bruce (1945) have now reported that anaemia in chicks fed on a purified diet can be completely prevented by giving folic acid, together with the above lactone or the isomeric lactone derived from 2-methyl-3-hydroxy-4-carboxy-5-hydroxymethylpyridine ( $\beta$-pyracin). These two derivatives of pyridoxin must, therefore, be regarded as anti-anaemia factors for the chick.
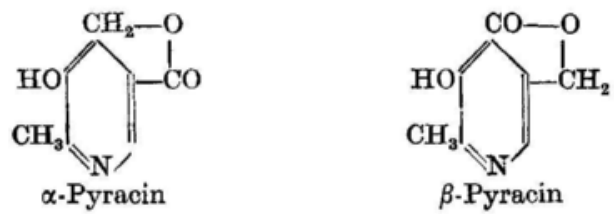

Folic acid proved to be effective also in curing the symptoms caused by administration of certain sulphonamides to rats (Martin, 1942; Ransone and Elvehjem, 1943). These symptoms are very similar to those of vitamin B complex deficiency, loss or greying of hair being characteristic. Various workers have from time to time reported that this achromotrichia or alopecia can be cured by giving pantothenic acid, inositol or $p$-aminobenzoic acid, and it was difficult to reconcile these conflicting statements. It is now believed that either the addition of sulphonamides or the absence of one or more essential vitamins depresses or inhibits the growth of the intestinal flora from which these factors are normally derived. The addition of one or other of the missing factors enables the others to be synthesized by stimulating the growth of the bacteria that produce them.

Daft and Sebrell (1943) observed that crystalline folic acid cured also the leucopenia and granulocytopenia induced in rats by administration of sulphaguanidine and sulphasuxidine, a condition which resembles that arising in monkeys fed on a synthetic diet. Langston, Darby, Shukers and Day (1938) found that monkey anaemia was relieved by concentrates of yeast and liver and suggested the name vitamin $\mathbf{M}$ for the responsible factor. The resemblance between the symptoms of vitamin M deficiency and those observed in rats treated with sulphonamides prompted 
Totter and Day (1943) to test the so called fish anaemia factor, xanthopterin, in these conditions. Xanthopterin is the yellow pigment found in the wings of the brimstone butterfly and was shown by Simmons and Norris (1941) to cure anaemia in trout and by Tschesche and Wolf (1937) to curo anaemia in rats induced by feeding on goat's milk. Totter and Day (1943) and Totter, Shukers, Kolson, Mims and Day (1943) found that xanthopterin would relieve the blood changes in nutritional cytopenia in the monkey, but not the other symptoms of vitamin M deficiency; it cured also the leucopenia of rats treated with sulphasuxidine.

Folic acid behaved similarly (Totter, Mims and Day, 1944; Totter, Shukers, Kolson, Mims and Day, 1944), whereas pantothenic acid, choline, $p$-aminobenzoic acid, pyridoxin and inositol were withont effect in vitamin M deficiency. Day, Mims, Totter, Stokstad, Hutchings and Sloane (1945) claim to have relieved the cytopenia due to vitamin M deficiency also with the highly purified $L$. casei factor of Stokstad. Folic acid was effective in fish anaemia (Mitchell and Williams, 1944), but had only one-fifth the activity of xanthopterin.

It is obvious, therefore, that whilst folic acid and vitamin $B_{c}$ are probably identical, they differ in some respects from vitamin $\mathbf{M}$ on the one hand and from xanthopterin on the other. The close relationship between all these factors is supported by other evidence. Thus, Mitchell (1944) showed that folic acid and xanthopterin possess similar absorption spectra, and Bloom, Vandenbelt, Binkley, O'Dell and Pfiffner (1944) showed this to be true of vitamin $B_{c}$ and xanthopterin. Folic acid, vitamin $B_{c}$ and xanthopterin all contain a high percentage of nitrogen and may belong to the same group of chemical compounds. The structure of xanthopterin is known:

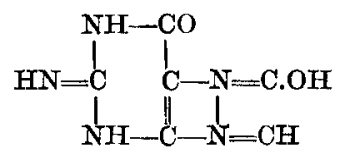

Its empirical formula is therefore $\mathrm{C}_{6} \mathrm{H}_{5} \mathrm{O}_{2} \mathrm{~N}_{5}$. Crystalline vitamin $\mathrm{B}_{\mathrm{c}}$ has been given the formula $\mathrm{C}_{9} \mathrm{H}_{10} \mathrm{~N}_{3} \mathrm{O}_{3}$ and a concentrate of folic acid, the formula $\mathrm{C}_{15} \mathrm{H}_{15} \mathrm{O}_{8} \mathrm{~N}_{5}$ (Mitchell and Williams, 1944). The composition of pure folic acid has not yet been published, however, and until this is known it cannot be assumed that vitamin $B_{c}$ and folic acid are identical.

Another link between xanthopterin and folic acid is provided by the evidence of Wright and Skeggs (1944) that addition of xanthopterin to cultures of Aerobacter aerogenes resulted in a marked reduction in the amount of folic acid synthesized by the organism; these workers suggested either that xanthopterin can partially replace folic acid as an essential growth factor for this organism or that its similarity to a hypothetical intermediate enables it to inhibit the synthesis or utilization of the intermediate. Wright, Skeggs and Welch (1944) showed also that the folic acid content of incubated rat liver may be increased by the presence of xanthopterin. Although the possibility that xanthopterin may be a precursor of folic acid was not excluded, they believe that the real explanation of this phenomenon is that folic acid is converted by liver enzymes into a substance that is microbiologically inactive and that vol. 4, 1946] 
xanthopterin inhibits this conversion. Stokes, Keresztesy and Foster (1944) claim to have obtained another factor which does not give rise to folic acid when incubated with rat liver but which appears to be able to replace folic acid in the nutrition of $S$. lactis $\mathrm{R}$ but not of $L$. casei $\epsilon$.

The only suggestion so far put forward of the role played by folic acid is due to Stokes $(1944,1,2)$, who found that thymine and its nucleoside, thymidine, could completely replace folic acid as a growth factor for $S$. lactis $\mathbf{R}$, though only at a 5000 -fold concentration. Other purines and pyrimidines were ineffective, and it is suggested that folic acid is a coenzyme in the synthesis of thymine.

A folic acid concentrate and a crystalline $L$. casei factor were found by Leuchtenberger, Lewisohn, Laszlo and Leuchtenberger (1944) to inhibit the growth of tumours, whilst Hertz and Sebrell (1944) found that the L. casei factor, presumably folic acid, restored the ability of stilboestrol to stimulate the oviducts of chicks when this was impaired by administration of a synthetic diet. Chicks deprived of pantothenic acid showed no such failure to respond to stilboestrol. It is evident, therefore, that folic acid may come to have important therapeutic applications.

\section{p-Aminobenzoic Acid}

$p$-Aminobenzoic acid is another substance now included in the vitamin $B$ complex. It was discovered as a result of the observation that the antibacterial action of sulphanilamide was inhibited by the addition of various yeast extracts. When these were fractionated, it was found that the most potent fraction had properties very similar to those of $p$-aminobenzoic acid and, when the effect of $p$-aminobenzoic acid itself was tested, it was found to neutralize the growth inhibiting properties of sulphanilamide. Experiments with animals showed that in the absence of $p$-aminobenzoic acid, greying and loss of hair occurred, which could be prevented or cured by the addition of $p$-aminobenzoic acid. As already mentioned, other factors appear to be associated with this condition owing to their ability to stimulate the growth of the intestinal flora, which synthesizes the missing factors. It has been established that some animals, including man, can derive aneurin, nicotinic acid and riboflavin from bacteria growing in the intestinal tract, but it is doubtful if the phenomenon is of general occurrence in man; if it were, it is difficult to see how the water soluble vitamins would ever have been discovered at all. I think it is very significant that the less well known members of the vitamin $B$ complex are not associated with specific deficiency diseases and this, I suggest, is due to the fact that they are mainly supplied by the intestinal flora.

Recently, Wright and Welch (1944) reported that rats fed on a synthetic diet containing a quantity of each member of the vitamin $B_{2}$ complex sufficient for normal growth and given sulphasuxidine showed a reduction in the amount of pantothenic acid, biotin and folic acid, but not of riboflavin and nicotinic acid, stored in the liver. The administration of biotin and folic acid resulted in the storage, not only of these two factors, but also of pantothenic acid. Besides establishing that biotin and folic acid are essential for the proper utilization of pantothenic acid these very significant results point to a clear distinction between riboflavin and nicotinic acid on the one hand, and the other members of 
the vitamin $B_{2}$ complex on the other. $A$ useful working hypothesis on which to base future research is that the essential requirements of riboflavin, nicotinic acid and aneurin are normally provided in the food, whilst sufficient amounts of pyridoxin, pantothenic acid, folic acid and biotin may be, and often are, supplied by bacterial synthesis in the intestine. The food intake may of course make a substantial contribution, but where the food is grossly deficient in this second group of factors, no serious symptoms will develop as they do with a deficiency of aneurin, nicotinic acid or riboflavin.

\section{Other Members of the Vitamin $B_{2}$ Complex}

This discussion has by no means covered all the members of the vitamin $\mathrm{B}_{2}$ complex which have been described in the literature. The status of the heat labile vitamin $B_{3}$ (Williams and Waterman, 1928) and vitamin $B_{5}$ (Carter, Kinnersley and Peters, 1930, 1,2) which were claimed to be necessary for the growth of pigeons, has never been settled, since pigeons have not been used in nutritional work since the early days of vitamin $B_{1}$ research; it is possible that these factors may be identical with vitamin $B_{\mathbf{c}}$ or other factors recently described. Some doubt has always existed concerning the claims for vitamin $\mathrm{B}_{4}$, first described by Reader (1929), though Kline, Elvehjem and Hart (1936) state that it is essential for the growth of rats given purified casein, crystalline aneurin and a concentrate of "vitamin $B_{2}{ }^{\prime \prime}$. No recent work has been carried out on vitamins $B_{3}, B_{4}$ or $B_{5}$.

Another factor which appears to have been neglected in recent years is the factor for preventing grey hair in silver foxes, called by Lunde and Kringstad (1939) vitamin $\mathrm{B}_{\mathbf{x}}$. This factor is heat labile and not adsorbed by fuller's earth.

The most important new factors recently described are vitamins $B_{10}$ and $B_{11}$, said by Briggs, Luckey, Elvehjem and Hart $(1943,1944)$ to be essential for the feathering and growth, respectively, of chicks. These new factors are certainly different from folic acid and, according to Mills, Briggs, Luckey and Elvehjem (1944), are produced by a certain strain of Mycobacterium tuberculosis, especially in presence of $p$-aminobenzoic acid.

Numerous factors also have been described as essential for the growth of various micro-organisms but, until more is known about their properties, it is impossible to estimate their importance or to hazard a guess at their relationship to the other factors already described in this review. They include Pollack and Lindner's (1943) L. casei factor, the factors stated by Chattaway, Happold, Sandford, Lythgoe and Todd (1943), Dolby, Happold and Sandford (1944) and Chattaway, Happold and Sandford (1944) to be necessary for the growth of Corynebacterium diphtheriae and L. casei, orotic acid (uracil-4-carboxylic acid) (Chattaway, 1944), the chloroform soluble factors from liver stated by Barton-Wright, Emery and Robinson (1944) to stimulate the growth of $L$. helveticus and $S$. lactis $\mathrm{R}$, a yeast factor required by $S$. lactis (Smith, 1943) probably identical with streptogenin (Sprince and Woolley, 1944), and the peptone factor of Chu and Williams (1944).

No review of the vitamin $B$ complex would be complete without reference to the lipotropic factors, inositol, choline and methionine. These should be regarded for the present as forming a third sub-group vox. 4, 1946] 
of the vitamin $B_{2}$ complex, although inositol is clearly related in some way to $p$-aminobenzoic acid and the other anti-alopecia factors.

Administration of inositol prevents the formation of fatty livers produced in rats on certain diets (Gavin and McHenry, 1941) whilst administration of choline prevents the formation of fatty livers due to the giving of large amounts of cholesterol or sucrose, and comparatively little protein (Best, Channon and Ridout, 1934; Aylward, Channon and Wilkinson, 1935). Choline is essential also for the growth of chicks (Hegsted, Mills, Elvehjem and Hart, 1941).

Du Vigneaud, Cohn, Chandler, Schenek and Simmonds (1941) found that the amino-acid, methionine, also would prevent fatty livers and that it functioned by transferring methyl groups to amino-ethanol, with formation of choline. Methionine and choline were effective also in preventing the development of a haemorrhagic condition of the kidneys. The mechanism by which choline acts is still obscure. Best (1934) suggested that it accelerates the oxidation of fat in the liver, while others have suggested that it is converted into lecithin or some other phospholipin, capable of romoving fat from the liver. Gavin, Patterson and McHenry (1943) were able to distinguish between the effects of choline and inositol on livers which had become fatty from different causes. Thus, choline was effective in fattiness of the liver due to aneurin or cholesterol, but not to biotin, while inositol was effective when the cause was cholesterol or biotin but not aneurin. From this evidence it would seem that inositol and choline must act in different ways, but the problem is still one of extreme obscurity.

\section{REFERENCES}

Aylward, F. X., Channon, H. J. and Wilkinson, H. (1935). Biochem. J. 29, $16_{6}$.

Barton-Wright, E. C., Emery, W. B. and Robinson, F. A. (1944). Nature, Lond., 153, 771 .

Best, C. H. (1934). Lancet, 226, 1274.

Best, C. H., Channon, H. J. and Ridout, J. H. (1934). J. Physiol. 81, 409.

Binkley, S. B., Bird, O. D., Bloom, E. S., Brown, R. A., Calkins, D. G., Campbell, C. J., Emmett, A. D. and Pfiffner, J. J. (1944). Science, 100, 36.

Bloom, F. S., Vandenbelt, J. M., Binkley, s. B., O'Dell, B. L. and Pfiffner, J. J. (1944). Science, 100, 295.

Briggs, G. M., Luckey, T. D., Elvehjem, C. A. and Hart, E. B. (1943). J. biol. Chem. 148, 163.

Briggs, G. M., Luckey, T. D., Elvehjorn, C. A. and Hart, E. B. (1944). J. biol. Chem. 153, 423.

Campbell, C. J., Brown, R."A. and Emmett, A. D. (1944). J. biol. Chem. 152, 483. Carter, C. W., Kinnersley, H. W. and Peters, R. A. (1930, 1). Biochem. J. 24, 1832.

Carter, C. W., Kinnersley, H. W. and Peters, R. A. (1930, 2). Biochem. J. 24, 1844.

Chattaway, F. W. (1944). Nature, Lond., 153, 250.

Chattaway, F. W., Happold, F. C. and Sandford, M. (1944). Biochem. J. 38, 111.

Chattaway, F. W., Happold, F. C., Sandford, M., Lythgoe, B. and Todd, A. R. (1943). Nature, Lond., 151, 559.

Chu, E. J. and Williams, R. J. (1944). J. biol. Chem. 155, 9.

Daft, F. S. and Sebrell, W. H. (1943). Publ. Hlth Rep., Wash., 58, 1542.

Day, P. L., Mims, V., Totter, J. R., Stokstad, E. L. R., Hutchings, B. L. and Sloane, N. H. (1945). J. biol. Chem. 157, 423.

Dolby, D. E., Happold, F. C. and Sandford, M. (1944). Nature, Lond., 153, 619.

Du Vigneaud, V., Cohn, M., Chandler, J. P., Schenck, J. R. and Simonds, S. (1941). J. biol. Chem. 140, 625.

Du Vigneaud, V., Hofmann, K. and Melville, D. B. (1941). J. biol. Chem. 140, 643.

Du Vigneaud, V., Melville, D. B., Folkers, K., Wolf, D. E., Mozingo, R., Keresztesy, J. C. and Harris, S. A, (1942). J. biol. Chem. 146, 475. 
Du Vigneaud, V., Spangler, J. M., Burk, D., Kensler, C. J., Sugiura, K. and Rhoads, C. P. (1942). Science, 95, 174.

Elvehjem, C. A. and Koehn, C. J. (1935). J. biol. Chem. 108, 709.

Frieden, E. H., Mitchell, H. K. and Williams, R. J. (1944). J. Amer. chem. Soc. 66, 269.

Gavin, G, and McHenry, E. W. (1941). J. biol. Chem. 139, 485.

Gavin, G., Patterson, J. M. and MeHenry, E. W. (1943). J. biol. Chem. 148, 275.

Gunsalus, I. C. and Bellamy, W. D. $(1944,1)$. J. biol. Chem. 155, 357.

Gunsalus, I. C. and Bellamy, W. D. (1944, 2). J. biol. Chem. 155, 557.

Gunsalus, I. C., Bellamy, W. D. and Umbreit, W. W. (1944). J. biol. Chem. 155, 685.

György, P. (1938). J. Amer. chem. Soc. 60, 983.

Harris, S. A. and Folkers, K. $(1939,1)$. J. Amer. chem. Soc. 61, 1245 .

Harris, S. A. and Folkers, K. (1939, 2). J. Amer. chem. Soc. 61, 3307.

Harris, S. A., Heyl, D. and Folkers, K. (1944, 1). J. Amer. chem. Soe. 66, 2088.

Harris, S. A., Heyl, D. and Folkers, K. $(1944,2)$. J biol. Chem. 154, 315.

Harris, S. A., Stiller, E. T. and Folkers, K. (1939). J. Amer. chem. Soc. 61, 1242.

Harris, S. A., Wolf, D. E., Mozingo, R., Anderson, R. C., Arth, G. E., Easton, N. R., Heyl, D., Wilson, A. N. and Folkers, K. (1944). J. Amer, chem. Soc. 66,1756 .

Hegsted, D. M., Mills, R. C., Elvehjem, C. A. and Hart, E. B. (1941). J. biol. Chem. 138, 459 .

Hertz, R. and Sebrell, W. H. (1944). Science, 100, 293.

Hill, F. W., Norris, L. C. and Heuser, G. F. (1944). J. Nutrit. 28, 175.

Hutchings, B. L., Stokstad, E. L. R., Bohonos, N, and Slobodkin, N. H. (1944). Science, 99, 371 .

Ichiba, A. and Michi, K. (1939). Sci. Pap. Inst. phys. chem. Res. Tokyo, 36, 173

Jukes, T. H. (1939). J. Amer, chem. Soc. 67, 975.

Keresztesy, J. C. and Stevens, J. R. (1938). J. Amer. chem. Soc. 60, 1267.

Kline, O. L., Elvehjem, C. A. and Hart, E. B. (1936). Biochem. J. 30, 780.

Kögl, F. and Tönnis, B. (1936). Hoppe-Seyl. Z. 242, 43.

Krueger, K. and Peterson, W. H. (1945). J. biol. Chem. 158, 145.

Kuhn, R. and Wendt, G. (1938, 1). Ber, dtsch. chem. Ges. 71, 780.

Kuhn, R. and Wendt, G. (1938, 2). Ber. dtsch. chem. Ges. 71, 1118.

Kuhn, R. and Wendt, G. (1938, 3). Ber. dtsch. chem. Ges. 71, 1534.

Kuhn, R. and Wendt, G. (1939). Ber. dtsch. chem. Ges. 72, 305.

Kuhn, R., Westphal, K., Wendt, G. and Westphal, O. (1939). Naturwissenschaften, 27,470 .

Langston, W. C., Darby, W. J., Shukers, C. P. and Day, P. L. (1938). J. exp. Med. 68, 923.

Lepkovsky, S. (1938). J. biol. Chem. 124, 125.

Leuchtenberger, C., Lewisohn, R., Lasslo, D. and Leuchtenberger, R. (1944). Proc. Soc. exp. Biol., N.Y., 55, 204.

Lunde, G. and Kringstad, H. (1939). Naturwissenschaften, 27, 75.5.

Martin, G. J. (1942). Proc. Soc. exp. Biol., N.Y., 51, 353.

Melville, D. B., Moyer, A. W., Hofnamn, K. and du Vigneaud, V. (1942). J.biol. Chem. 146, 487.

Mills, R. C., Briggs, G. M., Luckey, T. D. and Elvehjem, C. A. (1944). Proc. Soc. $\exp$. Biol., N.Y., 56, 240.

Mitchell, H. K. (1944). J. Amer. chem. Soc. 66, 274.

Mitchell, H. K., Snell, E. E. and Williams, R. J. (1941). J. Amer. chem. Soc. 63, 2284.

Mitchell, H. K., Snell, E. E. and Williams, R. J. (1944). J. Amer. chem. Soc. 66, 267.

Mitchell, H. K. and Williams, R. J. (1944). J. Amer. chem. Soc. 66, 271.

Mueller, J. H. (1937). J. biol. Chem. 119, 121.

O'Dell, B. L. and Hogan, A. G. (1943). J. biol. Chem. 149, 323.

Pennington, D. E., Snell, E. E. and Eakin, R. E. (1942). J. Amer. chem. Soc. 64, 469 .

Pollack, M. A. and Lindner, M. (1943). J. biol. Ohem. 147, 183.

Ransone, B. and Elvehjem, C. A. (1943). J. biol. Chem. 151, 109.

Reader, V. (1929). Biochem. J. 23, 689.

Richardson, L. R., Hogan, A. G. and Karrasch, R. J. (1942). J. Nutrit. 24, 65.

vor. 4, 1946] 
Schlenk, F. and Snell, E. E. (1945). J. biol. Chem. 157, 425.

Scott, M. L., Norris, L. C., Heuser, G. F. and Bruce, W. F. (1945). J. biol. Chem. $158,291$.

Seott, M. L., Norris, L. C., Heuser, G. F., Bruce, W. F., Coover, H. W., Bellamy, W. D. and Gunsalus, I. C. (1944). J. biol. Chem. 154, 713.

Simmons, R. W. and Norris, E. R. (1941). J. biol. Chem. 140, 679.

Smith, F. R. (1943). J. Bact. 46, 369 .

Snell, E. E. and Rannefeld, A. N. (1945). J. biol. Chem. 157, 475.

Sprince, H. and Woolley, D. W. (1944). J.exp. Med. 80, 213.

Stiller, E. T., Harris, S. A., Finkelstein, J., Keresztesy, J. C. and Folkers, K. (1940). J. Amer. chem. Soc. 62, 1785.

Stiller, F. T., Keresztesy, J, C. and Stevens, J. R. (1939). J. Amer, chem. Soe. 61, 1237.

Stokes, J. L. $(1944$, I). J. Bact. 47, 433.

Stokes, J. L. (1944, 2). J. Bact. 48, 201.

Stokes, J. L., Koresztesy, J. C. and Foster, J. W. (1944). Science, 100, 522.

Stokstad, E. L. R. (1943). J. biol. Chem. 149, 573.

Subbarow, Y. and Hitchings, G. H. (1939). J. Amer. chem. Soc. 61, 1615.

Sydenstricker, V. P., Singal, S. A., Briggs, A. P., de Vaughn, N. M. and Isbell, H. (1942, 1). Science, 95, 176.

Sydenstricker, V. P., Singal, S. A., Briggs, A. P., de Vaughn, N. M. and Isbell, H. $(1942,2)$. J. Amer. med. Ass. 118, 1199.

Totter, J. R. and Day, P. L. (1943). J. biol. Chem. 147, 257.

Totter, J. R., Mims, V. and Day, P. L. (1944). Science, 100, 223.

Totter, J. R., Shukers, C. F., Kolson, J., Mims, V. and Day, P. L. (1943). Fed. Proc. 2, 72.

Totter, J. R., Shukers, C. F., Kolson, J., Mims, V. and Day, P. L. (1944). J. biol. Chem. 152, 147 .

Tschesche, R. and Wolf, H. J. (1937). Hoppe-Seyl. Z. 248, 34.

Waisman, H. A., McCall, K. B. and Elvehjem, C. A. (1945). J. Nutrit. 29, 1.

Wildiers, E. (1901). Cellule, 18, 313.

Williams, R. R. and Waterman, R. E. (1928). J. biol. Chem. 78, 311 .

Woolley, D. W. and Sprince, H. (1944). J. biol. Chem. 153, 687.

Wright, L. D. and Skeggs, H. R. (1944). Proc. Soc. exp. Biol., N.Y., 55, 92.

Wright, L. D., Skeggs, H. R. and Welch, A. D. (1944). Fed. Proc. 3, 88.

Wright, L. D. and Welch, A. D. (1.844). J. Nutrit. 27, 55.

\title{
Growth Factors and Growth Inhibitors for Micro-organisms
}

\author{
Dr. B. C. J. G. Knight (The Wellcome Physiological Research Laboratories, \\ Beckenham, Kent)
}

\section{Essential Metabolites}

We have had from Drs. Harris and Kodicek (1946) a survey of the substances of the vitamin $B$ complex considered from the point of view of their nutritional significance in higher animals, and from Dr. Quastel (1946) an account of those which are known as components of enzyme systems. These are two of the lines of investigation which have led to the chemical characterization of some of those substances which are now seen to contribute to fundamental metabolic processes common to the widest variety of cells. Of course, the observation of the wide distribution in nature of similar enzymic reactions already provided a basis for a belief in the fundamental unity of all biochemistry which Kluyver, for example, has always stressed, and which is implicit in our conception of the evolution of living organisms.

Originally the nutrient requirements of yeasts and bacteria also were independent fields of study, but these likewise have converged in the 